\title{
Environmental control on the variability of DMS and DMSP in the Mauritanian upwelling region
}

\author{
C. Zindler ${ }^{1}$, I. Peeken ${ }^{1,2,3}$, C. A. Marandino ${ }^{1}$, and H. W. Bange ${ }^{1}$ \\ ${ }^{1}$ Forschungsbereich Marine Biogeochemie, GEOMAR | Helmholtz-Zentrum für Ozeanforschung Kiel, \\ Düsternbrooker Weg 20, 24105 Kiel, Germany \\ ${ }^{2}$ Alfred-Wegener-Institut für Polar- und Meeresforschung, Bremerhaven, Germany \\ ${ }^{3}$ MARUM - Center for Marine Environmental Sciences Bremen, Germany \\ Correspondence to: C. Zindler (czindler@geomar.de)
}

Received: 17 August 2011 - Published in Biogeosciences Discuss.: 25 August 2011

Revised: 9 February 2012 - Accepted: 10 February 2012 - Published: 16 March 2012

\begin{abstract}
Dimethylsulphide (DMS) and dissolved and particulate dimethylsulfoniopropionate $\left(\mathrm{DMSP}_{\mathrm{d}}, \mathrm{DMSP}_{\mathrm{p}}\right)$ were measured in near-surface waters along the Mauritanian coast, Northwest Africa, during the upwelling season in February 2008. DMS, DMSP $\mathrm{d}_{\mathrm{d}}$ and $\mathrm{DMSP}_{\mathrm{p}}$ surface concentrations of up to $10 \mathrm{nmol} \mathrm{L}^{-1}, 15 \mathrm{nmol} \mathrm{L}^{-1}$ and $990 \mathrm{nmol} \mathrm{L}^{-1}$, respectively, were measured. However, the DMS concentrations measured are in the low range compared to other upwelling regions. The maximum DMSP $\mathrm{p}_{\mathrm{p}}$ concentration is the highest reported from upwelling regions so far, which might indicate that the Mauritanian upwelling is a hot spot for DMSP. Within the phytoplankton groups, dinoflagellates were identified as important contributors to DMS concentrations, while other algae seemed to have only a minor or no influence on DMS and DMSP concentrations. A pronounced switch from high DMSP to high DMS concentrations was observed when the nitrogen to phosphorus ratio $(\mathrm{N}: \mathrm{P})$ was below 7 . The high DMS/DMSP ratios at N:P ratios $<7$ indicate that nitrogen limitation presumably triggered a switch from DMSP to DMS independent of the species composition. Our results underline the importance of coastal upwelling regions as a local source for surface seawater sulphur.
\end{abstract}

\section{Introduction}

The oceanic distributions of dimethylsulphide (DMS) and its major precursor dimethylsulfoniopropionate (DMSP) result from a complex interplay of biological and non-biological pathways, such as formation by phytoplankton and microbial cleavage of DMSP to DMS, on the one hand, and microbial consumption as well as photochemical oxidation of DMS and its loss to the atmosphere, on the other hand (see, e.g. Schäfer et al., 2010; Simó, 2004; Stefels et al., 2007; Vogt and Liss, 2009). Biologically productive regions of the ocean are responsible for a significant fraction of the sea surface production of DMS and DMSP and are, therefore, potentially strong sources of atmospheric DMS (Kettle and Andreae, 2000; Lana et al., 2011). Once released to the atmosphere, DMS is a potential precursor of sulphur aerosols which can act as cloud condensation nuclei (see, e.g. Charlson et al., 1987; Faloona, 2009; Vogt and Liss, 2009).

Eastern Boundary Upwelling Systems, such as the one found along the Mauritanian coast of north western Africa, are known as highly productive oceanic areas because of the nutrient rich subsurface waters which upwell along the coast and induce pronounced phytoplankton blooms (see, e.g. Chavez and Messie, 2009; Minas et al., 1986). In various coastal upwelling regions a characteristic phytoplankton composition and succession has been observed, which depends on the nutrient supply in close association with the temporal and spatial settings of the upwelling events. Pronounced blooms of dinoflagellates and coccolithophorids, which are well known as important DMSP producing algae (Keller et al., 1989; Stefels et al., 2007), occur after the decline of the diatom bloom, which usually dominates during the first stage of an upwelling event. Therefore, coastal upwelling regions may be hot spots of DMS production. However, DMS emissions from coastal upwelling regions are more important as local rather than global phenomenon because of the small area coverage and the transient nature of upwelling events (Kettle and Andreae, 2000; Lana et al., 2011).

Despite the fact that coastal upwelling areas have been identified as hot spots of DMS production, only a few 


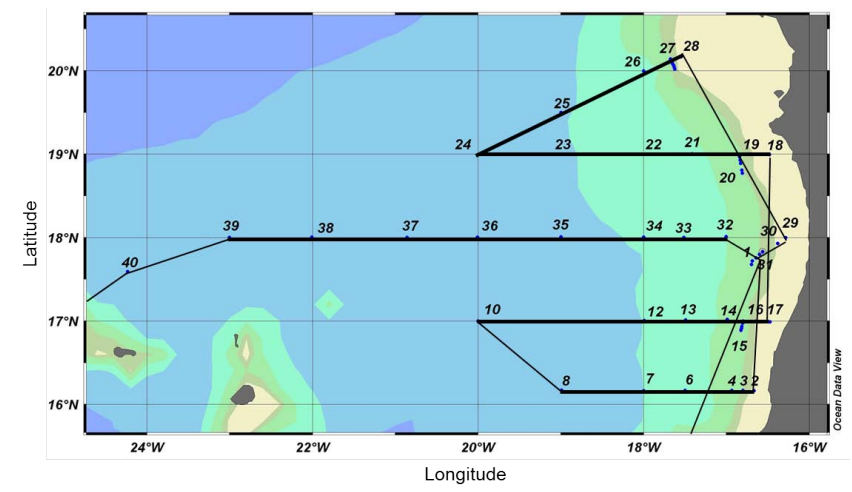

Fig. 1. Cruise track and locations of the sampling stations during the ATA-03 cruise in February 2008. Bold black lines indicate the onshore-offshore transects. The colour coding represents the bathymetry of the sampling area. Dark blue to light brown indicate deep waters $(3600 \mathrm{~m})$ to shallow waters $(50 \mathrm{~m})$.

descriptive studies about DMS from these areas have been published: DMS and DMSP have been measured in the Peruvian upwelling (Andreae, 1985; Riseman and DiTullio, 2004), off Oman (Hatton et al., 1999), off West India (Shenoy and Dileep Kumar, 2007) and in the NW African upwelling off Morocco (Belviso et al., 2003) as well as off Mauritania (Franklin et al., 2009). The parameters which influence the temporal development and spatial distribution of DMS as well as DMSP in coastal upwelling areas are not completely understood.

Here we present the DMS and DMSP distributions in surface waters along the Mauritanian coast during the upwelling period in February 2008. The influence of different parameters, such as nutrient availability and phytoplankton composition and succession, on the DMS and DSMP distributions within the plumes of upwelled waters was examined.

\section{Methods}

DMS and DMSP surface concentrations were measured during the ATA-03 study in the Mauritanian coastal upwelling region as well as in the open ocean between Mauritania and the Cape Verde Islands. The ATA-03 cruise was conducted on the French research vessel L'Atalante from 3-20 February 2008, as part of the German SOPRAN "Surface Ocean Processes in the Anthropocene" project (www.sopran.pangaea. de). Four short onshore-offshore transects were performed between $16^{\circ} \mathrm{W}$ and $20^{\circ} \mathrm{W}$, and a longer transect along $18^{\circ} \mathrm{N}$ between $16^{\circ} \mathrm{W}$ and $23^{\circ} \mathrm{W}$ (Fig. 1).

\subsection{DMS and DMSP analysis}

Surface seawater was sampled from 5 to $30 \mathrm{~m}$ depth in $250 \mathrm{ml}$ aliquots from a 24-Niskin bottle rosette equipped with a CTD. The samples were collected bubble-free in brown glass bottles sealed with gas tight PTFE coated lids. Three separate samples from these bottles were taken for DMS, dissolved DMSP $\left(\mathrm{DMSP}_{\mathrm{d}}\right)$ and particulate DMSP $\left(\mathrm{DMSP}_{\mathrm{p}}\right)$ analysis. Samples were measured immediately after sampling. However, during times with a high sampling frequency, a few samples were stored in the dark at $4{ }^{\circ} \mathrm{C}$ and measured within $4 \mathrm{~h}$ after sampling. In order to analyse the DMS and $\mathrm{DMSP}_{\mathrm{d}}$ concentrations, $25 \mathrm{ml}$ seawater was gently filtered through a glass fibre filter (GF/F; Whatman; $0.7 \mu \mathrm{m})$ attached to a syringe and measured using a purge and trap technique: Samples were purged with helium and the expelled DMS was preconcentrated on Tenax ${ }^{\circledR}$ TA (mesh 60/80, Alltech) at room temperature. A column filled with potassium carbonate $\left(\mathrm{K}_{2} \mathrm{CO}_{3}\right)$ was used as moisture trap. DMS was desorbed by heating the Tenax ${ }^{\circledR}$ TA to $200^{\circ} \mathrm{C}$ within 1 min using a heat gun and injected into a gas chromatograph (ICU 600 Carlo Erba Instruments; GC 6000 vega series 2; capillary column CP-SIL 5CB for sulphur, $30 \mathrm{~m} \times 0.32 \mathrm{~mm}$ ID) coupled to a flame photometric detector (FPD $800 \mathrm{CE}$ instruments) according to the methods of Kiene (1993) and Simó (1998). DMSP $_{d}$ and DMSP $_{p}$ were converted to DMS by hydrolysis with sodium hydroxide $(\mathrm{NaOH})$. The conversion time to form DMS from $\mathrm{DMSP}_{\mathrm{d}}$ and $\mathrm{DMSP}_{\mathrm{p}}$ was at least $12 \mathrm{~h}$ and $24 \mathrm{~h}$, respectively. $\mathrm{DMSP}_{\mathrm{d}}$ was measured directly out of the same sample after the analyses of DMS. For the determination of $\mathrm{DMSP}_{\mathrm{p}}, 3 \mathrm{ml}$ unfiltered alkalinized seawater was analysed for DMS. To obtain the final $\mathrm{DMSP}_{\mathrm{p}}$ values, the DMS and $\mathrm{DMSP}_{\mathrm{d}}$ concentrations were subtracted. The retention time for each sample was $1.5 \mathrm{~min}$. The $15 \mathrm{ml}$ samples and standards were purged for $15 \mathrm{~min}$. DMS standards were prepared as described in Kiene (1993) using liquid DMS diluted in ethylene glycol. Standards and samples were measured in triplicates and their standard deviations were calculated according to the statistical method of David (1951). The mean analytical errors were $\pm 0.3 \mathrm{nmol} \mathrm{L}^{-1}$ $( \pm 12 \%)$ for DMS, $\pm 0.8 \mathrm{nmol} \mathrm{L}^{-1}\left( \pm 19 \%\right.$ ) for $\mathrm{DMSP}_{\mathrm{d}}$ and $\pm 19 \mathrm{nmol} \mathrm{L}^{-1}( \pm 20 \%)$ for particulate DMSP . Calibrations were conducted every second day during the cruise. The analytical system was tested for blanks and sparging efficiency in the laboratory before the cruise. Blanks showed no DMS and the sparging efficiency was $100 \%$. Kiene and Slezak (2006) showed that syringe pressure filtration can artificially increase the $\mathrm{DMSP}_{\mathrm{d}}$ concentration in seawater samples; thus, it is possible that the $\mathrm{DMSP}_{\mathrm{d}}$ concentrations presented here are overestimated. Dissolved nutrients (nitrate, nitrite, phosphate and silicate) were measured on-board according to the methods described by Hansen and Koroleff (1999).

\subsection{Pigment analysis}

For the determination of pigments, $1-4 \mathrm{~L}$ of sea water were filtered onto $25 \mathrm{~mm}$ Whatman $\mathrm{GF} / \mathrm{F}$ filters with a pressure of less than 120 mbar. After filtration, the filters were folded and stored in $2 \mathrm{ml}$ micro centrifuge tubes (Eppendorf cups) at $-80^{\circ} \mathrm{C}$ until analysis. Samples were measured 
using a Waters HPLC-system equipped with an auto sampler (717 plus), pump (600), PDA (996), a fluorescence detector (474) and EMPOWER software. For analytical preparation, $50 \mu \mathrm{l}$ internal standard (canthaxanthin) and $2 \mathrm{ml}$ acetone were added to each filter sample and then homogenised for $3 \mathrm{~min}$ in a cell mill. After centrifugation, the supernatant liquid was filtered through a $0.2 \mu \mathrm{m}$ PTFE filter (Rotilabo) and placed in Eppendorf cups. An aliquot $(100 \mu \mathrm{l})$ was transferred to the auto sampler $\left(4^{\circ} \mathrm{C}\right)$. Just prior to analysis the sample was premixed with $1 \mathrm{M}$ ammonium acetate solution in the ratio $1: 1(\mathrm{v} / \mathrm{v})$ in the auto sampler and injected onto the HPLC-system. The pigments were analysed by reversephase HPLC, using a VARIAN Microsorb-MV3 $\mathrm{C}_{8}$ column $(4.6 \times 100 \mathrm{~mm})$ and HPLC-grade solvents (Merck). Solvent A consisted of $70 \%$ methanol and $30 \% 1 \mathrm{M}$ ammonium acetate, and solvent B contained $100 \%$ methanol. The gradient was modified after Barlow et al. (1997). Eluting pigments were detected by absorbance $(440 \mathrm{~nm})$ and fluorescence (Ex: $410 \mathrm{~nm}, \mathrm{Em}:>600 \mathrm{~nm})$. Pigments were identified by comparing their retention times with those of pure standards and algal extracts. Additional confirmation for each pigment was done with representative samples using on-line diode array absorbance spectra between 390-750 nm. Pigment concentrations were quantified based on peak areas of external standards, which were spectrophotometrically calibrated using extinction coefficients published by Bidigare (1991) and Jeffrey et al. (1997). For correction of experimental losses and volume changes, the concentrations of the pigments were normalised to the internal standard, canthaxanthin. This method separates chlorophyll- $a$ and divinyl chlorophyll- $a$ as well as lutein and zeaxanthin completely. Chlorophyll- $b$ and divinyl chlorophyll- $b$ are also distinguishable from each other, but they are not baseline separated. Chlorophyll- $a$ and divinyl chlorophyll- $a$ were combined to total chlorophyll- $a$ (TChl- $a$ ) in order to obtain a measure for the total amount of phytoplankton biomass in the sample. The taxonomic structure of phytoplankton communities was derived from photosynthetic pigment ratios using the CHEMTAX® program (Mackey et al., 1996), applying the input matrix of Veldhuis and Kraay (2004). The phytoplankton group composition is expressed in chlorophyll- $a$ concentrations.

\subsection{Statistical analysis}

A statistical approach was used to find correlations between the different environmental parameters (e.g. pigments, temperature, nutrients) and the dissolved sulphur compounds (MATLAB's "stepwisefit" tool): Terms were added and removed from a multi linear regression model based on their statistical significance. At each step an F-test was performed to test the regressions with and without certain terms. A term was added to the model if it contributed significantly at the $95 \%$-confidence level. A term was removed from the model if it did not contribute at the $99 \%$-confidence level.

\section{Results and discussion}

The coastal upwelling off Mauritania in February 2008 was characterized by significantly lower sea surface temperatures (SST), in the range of $18^{\circ}-20^{\circ} \mathrm{C}$ as compared to the open ocean SST of the adjacent eastern tropical North Atlantic $\left(>22^{\circ} \mathrm{C}\right.$ ) (Fig. 2). In general, the seasonally occurring upwelling between $15^{\circ} \mathrm{N}$ and $21^{\circ} \mathrm{N}$ has its strongest intensity and expansion between January and May whereas upwelling is persistent throughout the year north of $21^{\circ} \mathrm{N}$ (see, e.g. Mittelstaedt, 1991). In February 2008 upwelling occurred within a narrow band between $16^{\circ}-18^{\circ} \mathrm{W}$ along the continental margin located $50-100 \mathrm{~km}$ from the coast. The upwelling off Mauritania is driven by the north-easterly trade winds which trigger an offshore Ekman transport and result in an ascent of nutrient rich subsurface water (Minas et al., 1986; Mittelstaedt, 1991). The trade winds are deflected towards the Intertropical Convergence Zone (ITCZ), which is usually located around $6^{\circ} \mathrm{N}$ in February. Thus, the southward shift of the ITCZ during winter/spring induced an expansion of the coastal upwelling region to $16^{\circ} \mathrm{N}$ at the time of the ATA-03 cruise. Due to this effect, the upwelling plumes in the northern part of the sampling region $\left(>18^{\circ} \mathrm{N}\right)$ persisted longer and were more pronounced compared to the southern part $\left(<18^{\circ} \mathrm{N}\right)$. The different minimum SST of about $19^{\circ} \mathrm{C}$ in the northern part and $20^{\circ} \mathrm{C}$ in the southern part (Fig. 2) underline the different ages of the upwelling plumes. The $18^{\circ} \mathrm{N}$ transect was sampled last, ensuring that the upwelling at $18^{\circ} \mathrm{N}$ was also entirely developed, as indicated by a minimum SST of $18^{\circ} \mathrm{C}$ close to the coast (Fig. 2). The overall distribution of nutrients such as nitrate $\left(\mathrm{NO}_{3}^{-}\right)$and silicate in the surface layer off Mauritania was patchy with enhanced concentrations within and around the upwelling centres close to the coast (Fig. 2). Elevated chlorophyll- $a$ (chl- $a$, $7.4 \mu \mathrm{g} \mathrm{L}^{-1}$ ) concentrations coincided roughly with enhanced nutrient concentrations (Fig. 2).

\subsection{Phytoplankton distribution based on marker pigments}

Since a strong gradient in temperature from the open ocean towards the coast was observed for all transects, the water temperature is a good indicator of upwelling. Therefore, phytoplankton distributions have been sorted and plotted against temperature.

The major phytoplankton group in the upwelling were diatoms which contributed $60-90 \%$ to the total phytoplankton chlorophyll (Fig. 3). A significant correlation of the main marker pigment of diatoms, fucoxanthin, with chl- $a\left(R^{2}=0.96\right)$ further suggests that diatoms are mostly favoured in the upwelling close to the coast. Cyanobacteria (including Synechococcus, Prochlorococcus, Trichodesmium) were the major phytoplankton groups (50$80 \%)$ in the oligotrophic open ocean waters west of $18^{\circ} \mathrm{W}$ (Fig. 3). Dinoflagellates and Hapthophytes (including 


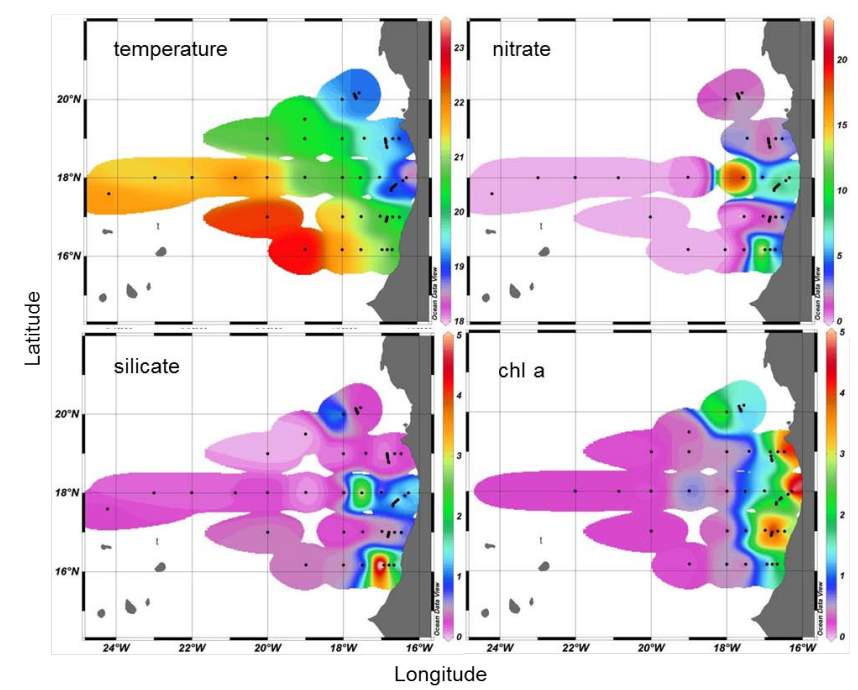

Fig. 2. Surface $(5 \mathrm{~m})$ distributions of temperature $\left[{ }^{\circ} \mathrm{C}\right]$, nitrate $\left[\mu \mathrm{mol} \mathrm{L}{ }^{-1}\right]$, silicate $\left[\mu \mathrm{mol} \mathrm{L}{ }^{-1}\right]$ and chlorophyll- $a(\mathrm{chl}-a)\left[\mu \mathrm{g} \mathrm{L}^{-1}\right]$ during ATA-03 in February 2008.

coccolithophorids) occurred mainly in the transition areas between nutrient rich upwelled waters and oligotrophic waters (Fig. 3). The dinoflagellates and haptophytes proportions of the phytoplankton community were $<20 \%$ and $<11 \%$, respectively, and thus low compared to diatoms and cyanobacteria. The pigment distribution was calculated using CHEMTAX® and is not based on direct individual pigment measurements. We observed low chl- $a$ concentrations but high silicate and nitrate concentrations in the most recently upwelled water south of $17^{\circ} \mathrm{N}$ (Fig. 2).

The distribution pattern of the phytoplankton community reflected a well characterized pattern of succession that normally occurs during spring blooms in the North Atlantic (Barlow et al., 1993): Diatoms are usually among the first phytoplankton species to occur and they dominate the nutrient (i.e. silicate) rich waters. Haptophytes and finally dinoflagellates succeed the diatoms. Both groups have a relatively lower nutrient demand. Cyanobacteria usually dominate oligotrophic open ocean waters and substantially contribute to the primary production in these regions (Campbell and Vaulot, 1993; Chisholm et al., 1988; Goericke and Welschmeyer, 1993; Veldhuis and Kraay, 2004; and Waterbury et al., 1986). The general succession of the phytoplankton was also observed off Mauritania in July/August 2006 by Franklin et al. (2009) towards the end of the upwelling season.

\subsection{N:P ratio}

The N:P ratio, here defined as the ratio of the sum of nitrate and nitrite $\left(\mathrm{NO}_{2}^{-}\right)$to phosphate $\left(\mathrm{PO}_{4}^{3-}\right)$, is a good indicator of the nutritional status of the surface waters off Mauritania (Fig. 4): High N:P ratios indicate freshly upwelled waters.

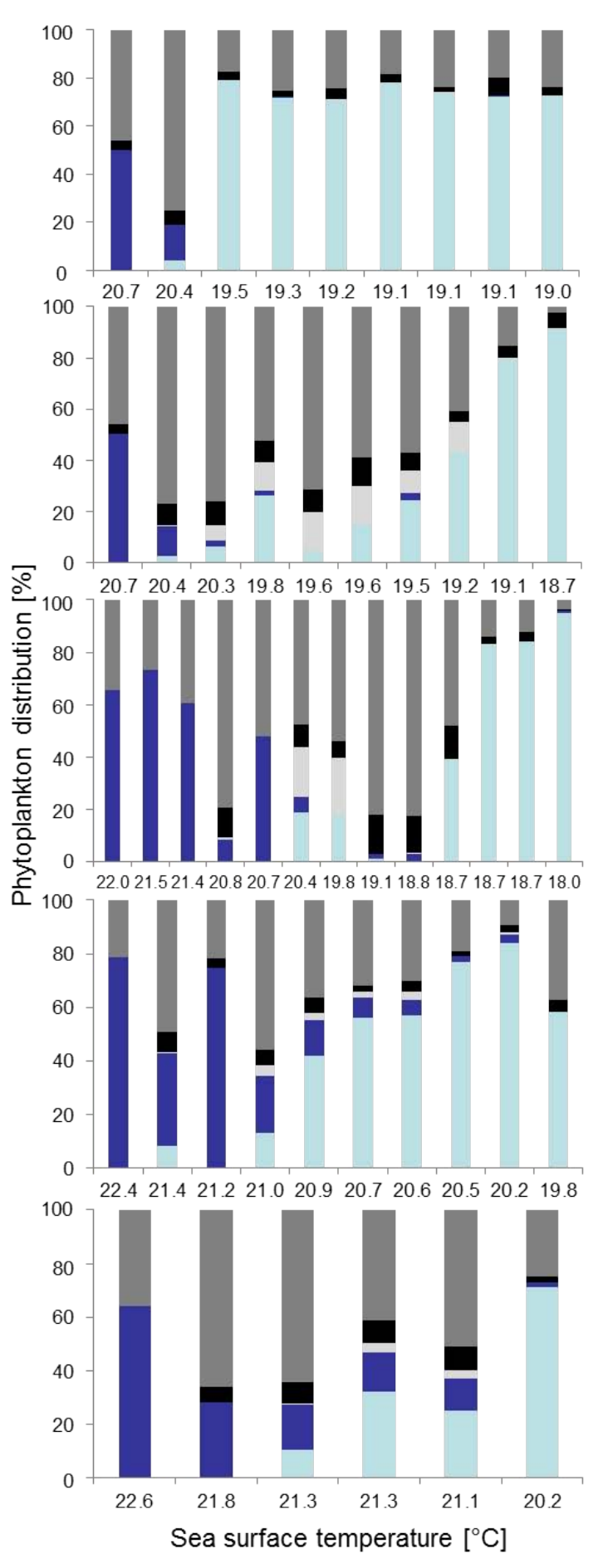

Fig. 3. Phytoplankton distribution in percentage based on their group specific chlorophyll concentration calculated by using the CHEMTAX® program: diatoms (light blue), cyanobacteria (dark blue), dinoflagellates (light grey), haptophytes (black) and other groups (including cryptophytes, chlorophytes, pelagophytes, dark grey) in $5 \mathrm{~m}$ depth along onshore-offshore transects between $16^{\circ}$ (lowest panel) and $20^{\circ} \mathrm{N}$ (upper panel). 


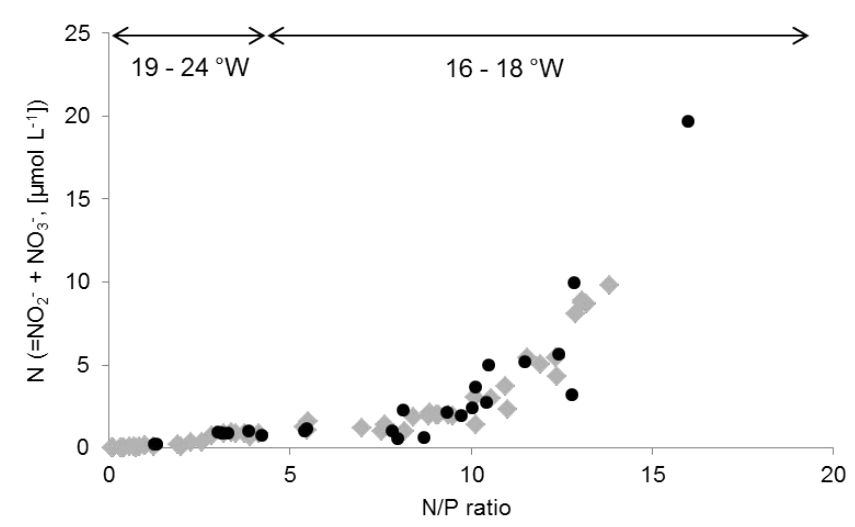

Fig. 4. Nitrogen $(\mathrm{N}=$ nitrate and nitrite) vs. $\mathrm{N}: \mathrm{P}$ ratios in surface water (5 m (grey diamonds) and 10 to $30 \mathrm{~m}$ (black dots)). P stands for dissolved phosphate.

Low $\mathrm{N}: \mathrm{P}$ ratios indicate $\mathrm{N}$ limited (i.e. aged) upwelled waters because $\mathrm{N}$ is consumed faster than $\mathrm{P}$. High $\mathrm{N}: \mathrm{P}$ ratios between 10 to 16 were detected in freshly upwelled waters close to the coast. The N:P ratios decreased to 0.1 towards the open ocean indicating a strong $\mathrm{N}$ depletion in the aged upwelled waters (Fig. 4). An N:P ratio of 16 (i.e. the classical Redfield ratio) was measured at $10 \mathrm{~m}$ depth close to the coast, whereas $\mathrm{N}: \mathrm{P}$ ratios of 13 or less were determined at $5 \mathrm{~m}$ depth. This illustrates the fast uptake of nutrients as a consequence of the almost immediate response of phytoplankton when nutrients are brought to the surface waters by upwelling.

\subsection{DMS and DMSP concentrations}

The median values for DMS and dissolved DMSP $\left(\mathrm{DMSP}_{\mathrm{d}}\right)$ surface $(5 \mathrm{~m})$ concentrations were $1.5 \mathrm{nmol} \mathrm{L}^{-1}$ (range $0.2-$ $10 \mathrm{nmol} \mathrm{L}^{-1}$ ) and $1.6 \mathrm{nmol} \mathrm{L}^{-1}$ (range $0.1-15 \mathrm{nmol} \mathrm{L}^{-1}$ ), respectively. The median of particulate DMSP $\left(\mathrm{DMSP}_{\mathrm{p}}\right)$ was $29 \mathrm{nmol} \mathrm{L}^{-1}$ (range $1.4-990 \mathrm{nmol} \mathrm{L}^{-1}$ ). The DMS concentrations in February 2008 are in line with previous measurements of DMS off the Mauritanian coast conducted from 1972 to 2006, which range from 0.05 to $19 \mathrm{nmol} \mathrm{L}^{-1}$ with a median value of $2.8 \mathrm{nmol} \mathrm{L}^{-1}$ (data extracted from the Global Surface Seawater DMS Database: http://saga. pmel.noaa.gov/dms). More recently, Franklin et al. (2009) measured DMS concentrations in the range from 1 to $14 \mathrm{nmol} \mathrm{L}^{-1}$ off Mauritania during the post upwelling season in July/August 2006. A comparison with data from other coastal upwelling areas reveals that the DMS concentrations off Mauritania are comparable with those found off Oman and off Morocco but they are considerably lower compared to those found off Peru and off West India (Table 1). The DMSP $_{\mathrm{p}}$ concentrations off Mauritania show a clear seasonal signal, with concentrations during the upwelling season significantly higher than those from the post upwelling season
(Table 1). The maximum DMSP $_{\mathrm{p}}$ concentration observed during this study off Mauritania is the highest reported from upwelling regions so far (Table 1). However, this high concentration could not be explained because it was only measured at a single station (16), with a moderate chl- $a$ concentration of $3.9 \mu \mathrm{g} \mathrm{L}^{-1}$ (DMSPp:chl- $a 0.2 \mathrm{nmol} \mu \mathrm{g}^{-1}$ ) dominated by diatoms (77\% of all algae) and a N:P ratio of 7.5.

\subsection{Factors influencing DMS and DMSP off Mauritania}

\subsubsection{Phytoplankton composition}

The DMS concentrations along the five transects were roughly associated with chl- $a$. We found statistically significant linear correlations with chl- $a$ at $16^{\circ} \mathrm{N}, 17^{\circ} \mathrm{N}$ and $19^{\circ} \mathrm{N}$ (Table 2, Fig. 5). For $\mathrm{DMSP}_{\mathrm{d}}$, a significant positive correlation with chl- $a$ was found only at $19^{\circ} \mathrm{N}$, whereas DMSP $_{\mathrm{p}}$ was not correlated with chl- $a$ (Table 2, Fig. 5). These findings most likely result from the fact that diatoms, which are not known to be important DMSP producing algae, were dominating the upwelling off Mauritania (the diatom marker pigment fucoxanthin was significantly correlated with chl- $a$, see above).

Additionally, the more pronounced transects in the north showed higher DMS:chl ratios compared to transects in the south (Table 2), indicating that DMS concentration increased with more aged upwelling. DMSP ${ }_{\mathrm{p}}$ :chl ratio was highest between $17^{\circ} \mathrm{N}$ and $18^{\circ} \mathrm{N}$ (Table 2), which showed a slight spatial separation between DMS and DMSP .

By using the statistical MATLAB tool "stepwisefit" (see Methods), a significant $\left(R^{2}=0.81, p<0.05, n=16\right)$ correlation was only found between DMS and peridinin, which is a marker pigment indicator for dinoflagellates. Using linear regression, a weak correlation was also detected between DMSP $_{\mathrm{p}}$ and peridinin $\left(R^{2}=0.36, p<0.05, n=16\right)$. We found only a weak correlation $\left(R^{2}=0.20, p<0.05, n=46\right)$ of DMSP with 19-hexanoyloxyfucoxanthin, which serves as a marker pigment for haptophytes, including the well-known DMSP producing coccolithophorids. It seems that DMSP produced by haptophytes was low in concentration or was consumed and converted rapidly. Steinke et al. (2002) found a high DMSP lyase activity (DLA) in dinoflagellates during a coccolithophorid bloom in the North Atlantic Ocean. They reported that dinoflagellates were responsible for a significant amount of the DMS production although their cell abundance was low. A significant correlation between DLA and dinoflagellate biomass as well as DLA and coccolithophorid biomass were found by Franklin et al. (2009) in the Mauritanian upwelling in 2006. Thus, it is reasonable to assume that dinoflagellates contributed significantly to the DMS concentrations in the Mauritanian upwelling during our study. However, in contrast to the results from Franklin et al. (2009), our results suggest that the portion of coccolithophorids to the DMS stock was less important in February 2008. 
Table 1. DMS and DMSP concentrations in coastal upwelling regions.

\begin{tabular}{|c|c|c|c|c|c|c|}
\hline Region & $\begin{array}{l}\text { DMS } \\
{\left[\mathrm{nmol} \mathrm{L}^{-1}\right]} \\
\text { Median } \\
\text { Range (min-max) }\end{array}$ & $\begin{array}{l}\mathrm{DMSP}_{\mathrm{d}} \\
{\left[\mathrm{nmol} \mathrm{L}^{-1}\right]} \\
\text { Median } \\
\text { Range (min-max) }\end{array}$ & $\begin{array}{l}\operatorname{DMSP}_{\mathrm{p}} \\
{\left[\mathrm{nmol} \mathrm{L}^{-1}\right]} \\
\text { Median } \\
\text { Range (min-max) }\end{array}$ & $\begin{array}{l}\text { Depth } \\
{[\mathrm{m}]}\end{array}$ & $\begin{array}{l}\operatorname{chl}-a \\
{\left[\mu \mathrm{g} \mathrm{L}^{-1}\right]}\end{array}$ & References \\
\hline \multicolumn{7}{|l|}{ Mauritania } \\
\hline 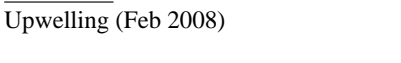 & $\begin{array}{l}1.5 \\
0.2-10\end{array}$ & $\begin{array}{l}1.6 \\
0.1-15\end{array}$ & $\begin{array}{l}29 \\
1.4-990\end{array}$ & $5-30$ & $0.08-7.4$ & This study \\
\hline Upwelling (Jan-Mar; avg. 1972-2006) & $\begin{array}{l}2.8 \\
0.05-19.2\end{array}$ & ng & ng & $0.5-8$ & $0.05-28$ & Global DMS Database ${ }^{(a)}$ \\
\hline Post upwelling (July/Aug 2006) & $\begin{array}{l}\text { ng } \\
1-14\end{array}$ & $\begin{array}{l}1.9 \\
<0.3-12\end{array}$ & $\begin{array}{l}6.5 \\
0.01-24\end{array}$ & $5-60$ & $10-120^{(\mathrm{d})}$ & Franklin et al., 2009 \\
\hline \multicolumn{7}{|l|}{ Morocco } \\
\hline Upwelling (Sept 1999) & $\begin{array}{l}\text { ng } \\
\text { up to } 16\end{array}$ & ng & $\begin{array}{l}\text { ng } \\
\text { up to } 150^{(\mathrm{b})}\end{array}$ & $3-5$ & $0.1-10$ & Belviso et al., 2003 \\
\hline \multicolumn{7}{|l|}{ Oman } \\
\hline Upwelling (Aug/Sept 1994) & 1.2 & 9 & 13 & $0-200$ & ng & Hatton et al., 1999 \\
\hline Post upwelling (Sept/Oct 1994) & $\begin{array}{l}<0.1-4.2 \\
2.9 \\
0.3-6.5\end{array}$ & $\begin{array}{l}<1.0-25 \\
14 \\
<1-42\end{array}$ & $\begin{array}{l}1.9-22 \\
19 \\
3-36\end{array}$ & & & Hatton et al., 1999 \\
\hline \multicolumn{7}{|l|}{ West India } \\
\hline Upwelling (Jun-Sept) & $\begin{array}{l}33^{(\mathrm{c})} \\
0.3-526\end{array}$ & ng & $\begin{array}{l}81^{(b),(c)} \\
2.0-916\end{array}$ & $<200$ & $0.2-0.7$ & $\begin{array}{l}\text { Shenoy and Dileep Kumar, } \\
2007\end{array}$ \\
\hline Non upwelling (October) & $\begin{array}{l}5.8^{(c)} \\
0.2-64\end{array}$ & ng & $\begin{array}{l}26^{(b)},(c) \\
0.5-160\end{array}$ & & & $\begin{array}{l}\text { Shenoy and Dileep Kumar, } \\
2007\end{array}$ \\
\hline$\underline{\text { Peru }}$ & & & & & & \\
\hline Upwelling (Jun/Jul 1982) & $\begin{array}{l}7.0^{(\mathrm{c})} \\
3->40\end{array}$ & $\mathrm{~nm}$ & $\mathrm{~nm}$ & 2 & $1.5-3$ & Andreae, 1985 \\
\hline Upwelling (September 2000) & $\mathrm{Nm}$ & $\mathrm{nm}$ & $\begin{array}{l}\mathrm{ng} \\
1.0-46\end{array}$ & $0-80$ & $0.4-1.6$ & $\begin{array}{l}\text { Riseman and DiTullio, } \\
2004\end{array}$ \\
\hline
\end{tabular}

(a) http://saga.pmel.noaa.gov/dms; ${ }^{\text {(b) }}$ given as $\mathrm{DMSP}_{\mathrm{t}}=\mathrm{DMSP}_{\mathrm{d}}+\mathrm{DMSP}_{\mathrm{p}}$; ${ }^{(\mathrm{c})}$ arithmetic mean; ng and nm stand for not given and not measured, respectively; ${ }^{(\mathrm{d})}$ in mg m ${ }^{-2}$ (water column integrated values)

Table 2. Ratios and correlations of DMS, DMSP with chlorophyll- $a$ for different transects in the Mauritanian upwelling region. No correlation could be found for DMSP $\mathrm{p}$ and chlorophyll- $a$.

\begin{tabular}{|c|c|c|c|c|c|c|}
\hline Transect & 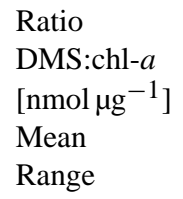 & $\begin{array}{l}\text { DMSP }_{\mathrm{d}}: \text { chl- } a \\
{\left[\mathrm{nmol} \mu \mathrm{g}^{-1}\right]} \\
\text { Mean } \\
\text { Range }\end{array}$ & $\begin{array}{l}\operatorname{DMSP}_{\mathrm{p}}: \mathrm{chl}-a \\
{\left[\mathrm{nmol} \mu \mathrm{g}^{-1}\right]} \\
\text { Mean } \\
\text { Range }\end{array}$ & 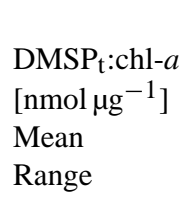 & $\begin{array}{l}\text { Significant correlation } \\
\text { DMS vs. chl- } a \\
{\left[\mathrm{nmol} \mathrm{L}^{-1}\right]\left[\mu \mathrm{L} \mathrm{L}^{-1}\right]}\end{array}$ & $\begin{array}{l}\text { DMSP }_{d} \text { vs. chl- } a \\
{\left[\mathrm{nmol} \mathrm{L}^{-1}\right]\left[\mu \mathrm{g} \mathrm{L}^{-1}\right]}\end{array}$ \\
\hline $19-20^{\circ} \mathrm{N}$ & $\begin{array}{l}4.13 \\
2.08-5.25\end{array}$ & $\begin{array}{l}3.83 \\
0.8-15.06\end{array}$ & $\begin{array}{l}112.29 \\
6.53-518.97\end{array}$ & $\begin{array}{l}85.58 \\
7.3-534\end{array}$ & no cor. & no cor. \\
\hline $19^{\circ} \mathrm{N}$ & $\begin{array}{l}2.26 \\
0.63-5.25\end{array}$ & $\begin{array}{l}3.85 \\
0.93-15.06\end{array}$ & $\begin{array}{l}98.40 \\
4.95-518.97\end{array}$ & $\begin{array}{l}102.25 \\
6.6-534\end{array}$ & $\begin{array}{l}R^{2}=0.51 \\
p<0.01 \\
n=12\end{array}$ & $\begin{array}{l}R^{2}=0.82 \\
p<0.01 \\
n=12\end{array}$ \\
\hline $18^{\circ} \mathrm{N}$ & $\begin{array}{l}7.19 \\
0.05-41.2\end{array}$ & $\begin{array}{l}6.31 \\
0.35-40.11\end{array}$ & $\begin{array}{l}204.19 \\
0.59-3527.34\end{array}$ & $\begin{array}{l}285.02 \\
0.9-2567.4\end{array}$ & no cor. & no cor. \\
\hline $17^{\circ} \mathrm{N}$ & $\begin{array}{l}0.47 \\
0.29-1.1\end{array}$ & $\begin{array}{l}0.94 \\
0.06-2.88\end{array}$ & $\begin{array}{l}134.88 \\
1.3-371.73\end{array}$ & $\begin{array}{l}135.82 \\
1.84-374.61\end{array}$ & $\begin{array}{l}R^{2}=0.51 \\
p<0.01 \\
n=16\end{array}$ & no cor. \\
\hline $16^{\circ} \mathrm{N}$ & $\begin{array}{l}1.04 \\
0.52-2.02\end{array}$ & $\begin{array}{l}4.65 \\
0.57-8.46\end{array}$ & $\begin{array}{l}65.56 \\
39.69-164.86\end{array}$ & $\begin{array}{l}70.21 \\
31.02-165.44\end{array}$ & $\begin{array}{l}R^{2}=0.56 \\
p<0.05 \\
n=10\end{array}$ & no cor. \\
\hline
\end{tabular}

chl- $a$, vs. and no cor. stands for chlorophyll- $a$, versus, and no correlation, respectively. 


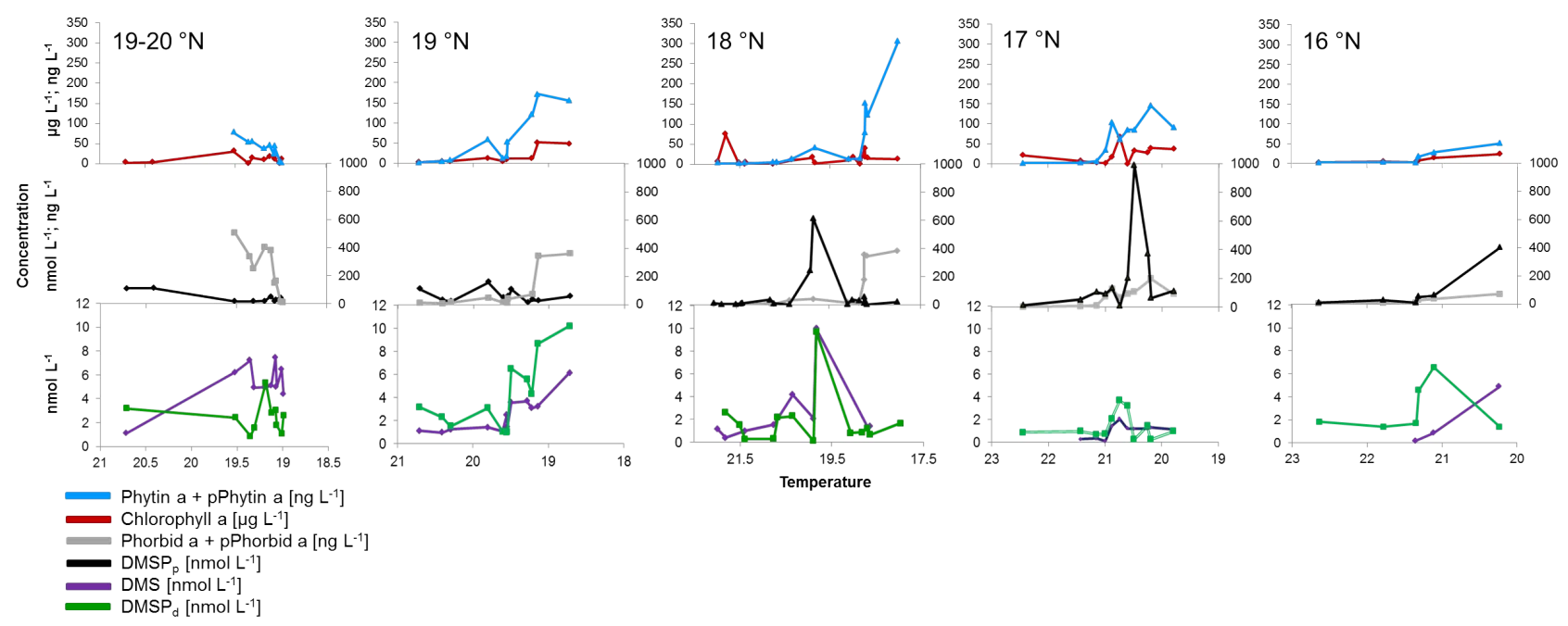

Fig. 5. Distribution of DMS, DMSP ${ }_{d}$, DMSP $_{\mathrm{p}}$, sum of Phorbid a and pPhorbid a, sum of Phytin a and pPhytin a and chlorophyll- $a$ in $5 \mathrm{~m}$ depth along onshore-offshore transects between $16^{\circ}$ and $20^{\circ} \mathrm{N}$.

The DMSP ${ }_{d}$ concentration showed a weak correlation with peridinin as well as with phytin a and phorbid a, which are indicators for phytoplankton senescence (Louda and Baker 1986) and grazing by zooplankton (Shuman and Lorenzen, 1975), respectively (Fig. 5). Nguyen et al. (1988) showed that DMSP producing algae were largely responsible for the production of $\mathrm{DMSP}_{\mathrm{d}}$ and DMS in seawater during their senescence stage. Archer et al. (2002), Simó et al. (2002), Saló et al. (2010) and Wolfe et al. (1996) showed that grazing zooplankton on DMSP producing algae can cause an increase in DMSP $_{d}$ and DMS. In this study, single stations showed an overlap between peaks of DMS and DMSP and peaks of high grazer and aged algae abundance (Fig. 5). These stations were located closest to the coast and were dominated by diatoms (60-90\%). Furthermore, the abundance of haptophytes was relatively low (4-5\%) and dinoflagellates did not occur. The concentration of marker pigments for grazing was two times higher than phytin a at the two coastal stations at the $19^{\circ} \mathrm{N}$ transect. DMS and $\mathrm{DMSP}_{\mathrm{d}}$ also showed one of their highest peaks with low $\mathrm{DMSP}_{\mathrm{p}}$ concentrations at the same two coastal stations. It seems that grazing had a stronger effect on the DMS and DMSP concentrations than on senescence. However, the overall influence of both of these factors on the DMS and DMSP distribution in the upwelling region is low, probably due to the relatively young upwelling stage along the Mauritanian coast at this time of the year.

\subsubsection{Mixed layer depth and solar radiation dose}

We also analysed the effect of mixed layer depth (MLD) and chl- $a$ as well as solar radiation dose (SRD) on the DMS concentrations according to the approaches of Simó and Dachs (2002) and Vallina and Simó (2007), respectively. The MLD was determined using the density criterion described by Kara et al. (2000). However, the measured DMS concentrations could neither be reproduced with the DMS versus chl/MLD approach $\left(R^{2}=0.04, n=27\right)$ and DMS/MLD approach $\left(R^{2}=0.24, n=7\right)$ nor with the DMS/SRD approach $\left(R^{2}=\right.$ $0.02, n=20$ ). The failure of the two algorithms to predict the DMS concentrations off Mauritania is most likely resulting from the fact that the algorithms are based on climatology data averaged over time and space. Our results are in line with recent findings, which indicated that the SRD may only account for 14-24\% of the variance of DMS measurements (Belviso et al., 2009; Derevianko et al., 2009). It was argued that using SRD only for predicting DMS concentrations does not account for biological production of DMS and may only be applicable when physical effects are large relative to the biological effects (Belviso et al., 2009; Derevianko et al., 2009), which is not the case for the upwelling off Mauritania. However, an influence of solar radiation on DMSP producing algae as well as a photochemical effect on the DMSP and DMS distributions cannot be fully excluded (see Sect. 3.4.3).

\subsubsection{N limitation}

In order to get an overall picture of the development of DMS and total DMSP $\left(\mathrm{DMSP}_{\mathrm{t}}=\mathrm{DMSP}_{\mathrm{d}}+\mathrm{DMSP}_{\mathrm{p}}\right)$ surface concentrations during the upwelling in February 2008, we calculated median DMS and $\mathrm{DMSP}_{\mathrm{t}}$ concentrations for $\mathrm{N}: \mathrm{P}$ bins from 0.5 to 16.5 (e.g. the median of DMS for N:P ratios between 6 to 7 was allocated to a N:P ratio of 6.5). Then the DMS and DMSP ${ }_{t}$ data were smoothed with a 3 point moving average. A bimodal distribution of both DMS and DMSP was found (Fig. 6). High DMSP ${ }_{t}$ and low DMS concentrations were observed at $\mathrm{N}: \mathrm{P}>7$, whereas low $\mathrm{DMSP}_{\mathrm{t}}$ and high DMS were observed for $\mathrm{N}: \mathrm{P}<7$. By correlating DMS with 


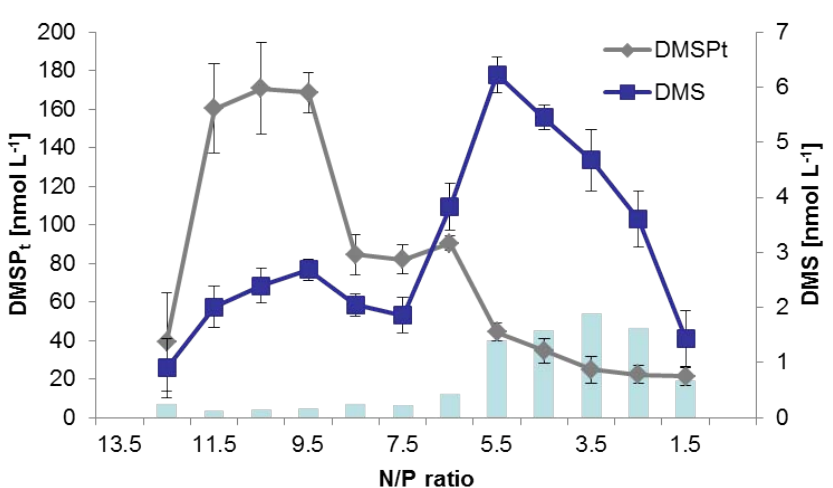

Fig. 6. N:P ratio vs. $\mathrm{DMSP}_{t}$ (grey diamonds) and DMS (blue squares) at $5 \mathrm{~m}$ depth. $\mathrm{N}$ stands for the sum of dissolved nitrate and nitrite, and $\mathrm{P}$ stands for phosphate. Blue bars show DMS:DMSP ratios.

$\mathrm{DMSP}_{\mathrm{t}}$, two distinct linear correlations were obvious for the two N:P regimes (Fig. 7). Thus, we conclude that there might have been a switch in the production and/or consumption of DMSP and DMS, depending on the availability of dissolved inorganic nitrogen (i.e. $\mathrm{NO}_{3}^{-}$and $\mathrm{NO}_{2}^{-}$) in the surface layer.

This observation agrees with the results of a study of DMSP production of nine strains of marine phytoplankton under N limitation (Gaul, 2004). The strains included dinoflagellates (Amphidinium cartearae, Heterocapsa pygmea, Prorocentrum redfieldii), haptophytes (Emiliania huxleyi, Calyptrosphaera spaeroidea, Prymnesium parvum), diatoms (Thalassiosira concaviuscula, Nitzschia spec.) and cryptophytes (Rhodomonas baltica). Gaul (2004) observed that all strains showed decreasing DMSP production rates with decreasing $\mathrm{N}$ concentrations. Moreover, the $\mathrm{N}$ specific DMSP production (i.e. the amount of DMSP produced per $\mu$ mol particulate organic nitrogen per day) showed pronounced maxima at dissolved inorganic $\mathrm{N}$ (DIN) concentrations in the range from 0.7 to $4.8 \mu \mathrm{mol} \mathrm{L}-1$ in six cultures (Gaul, 2004). For E. huxleyi CCMP373, Rh. baltica, and P. redfieldii, the $\mathrm{N}$ specific DMSP production showed a continuous decrease with decreasing dissolved DIN (Gaul, 2004). Unfortunately, the DMS concentrations were not monitored by Gaul (2004). In contrast, Bucciarelli et al. (2003) showed in culture experiments with Thalassiosira pseudonana an increase of DMSP under nitrogen limitation. It seems that the response on $\mathrm{N}$ limitation is dependent on algae species and their ability to handle stress. However, an increase in $\mathrm{DMSP}_{\mathrm{t}}$ with decreasing nitrogen until the $\mathrm{N}: \mathrm{P}$ ratio of 10 was also observed in the Mauritanian upwelling region (Fig. 6). Below the N:P ratio of 10 , the stress induced by $\mathrm{N}$-limitation is probably high enough to repress the DMSP accumulation as shown by Gaul (2004). However, this finding does not exclude the possibility that other nutrients might also be limiting, and thus may result in an unknown co-limitation of the phytoplankton community as described by the concept of Arrigo (2005).

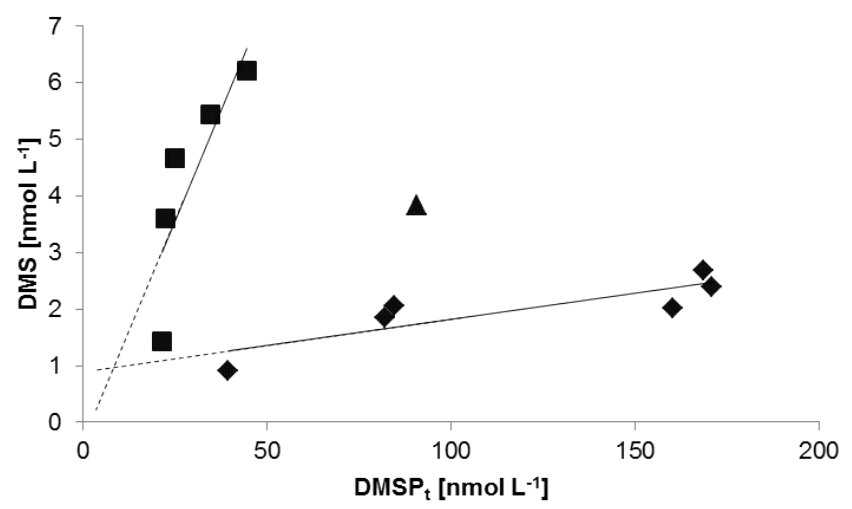

Fig. 7. Binned DMS vs. binned $\mathrm{DMSP}_{\mathrm{t}}$ : Upper regression line: $R^{2}=0.69$, DMS $=0.158 * \mathrm{DMSP}_{\mathrm{t}}-0.393$; lower regression line: $R^{2}=0.73, \mathrm{DMS}=0.001 * \mathrm{DMSP}_{\mathrm{t}}+0.893$; dashed lines are elongations of the regression lines. The triangle data point is not accounted for by the regression lines.

The results of a recent culture study of the coccolithophorid Emiliania huxleyi showed a 20 times increase of DMS concentrations under nitrogen limitation at a $\mathrm{N}: \mathrm{P}$ ratio of 3.2 (here $\mathrm{N}=$ ammonium or nitrate). The elevated DMS concentrations were explained by increased activity of the DMSP lyase under N limitation (Sunda et al., 2007). Bucciarelli et al. (2003) and Sunda et al. (2007) suggested that $\mathrm{N}$ limitation increases the oxidative stress within algae cells. This leads to increasing DMSP decomposition to DMS and acrylate, which are known for their ability to effectively scavenge harmful radicals such as hydroxyl radicals $(\mathrm{OH})$.

In addition to these laboratory experiments, a field study about DMS annual variability in the Baltic Sea by Leck et al. (1990) showed that enhanced DMS concentrations occurred in association with the depletion of inorganic nitrogen.

Other stressors such as UV radiation lead to enhanced DMS concentrations via increased DMSP decomposition as well (Archer et al., 2010; Sunda et al., 2002). Recently, Harada et al. (2009) suggested that exposure to UV radiation may lead to a significant decrease of DMSP in phytoplankton cells, but only when these cells are already suffering under $\mathrm{N}$ limitation. We conclude, therefore, that the oxidative stress induced by the increasing $\mathrm{N}$ limitation in combination with the high UV radiation in the tropical Atlantic off Mauritania might cause DMSP algae to increase DMSP decomposition, resulting in high DMS concentrations at $\mathrm{N}: \mathrm{P}<7$.

\subsubsection{DMS photolysis}

Various pathways of photochemical degradation of dissolved DMS have been proposed. DMS can react with various oxygen containing radicals such as hydrogen peroxide, singlet oxygen, and $\mathrm{OH}$, which are produced by photoexcitation of chromophoric dissolved organic matter (see, e.g. Vogt and 
Liss (2010) and references therein). Thus, upwelling events off Mauritania are ideally suited for DMS photodegradation because of the continuously high solar radiation in combination with the high concentrations of organic matter in the surface layer resulting from upwelling-driven productivity. An alternative photodegradation pathway has been suggested only recently: $\mathrm{NO}_{3}^{-}$photolysis in aqueous solutions generates $\mathrm{OH}$ radicals, which react with $\mathrm{Br}^{-}$to from $\mathrm{Br}_{2}^{-}$radicals, which in turn react with DMS (Bouillon and Miller, 2005). Indeed, Toole et al. (2004) showed that DMS photochemical degradation is increasing linearly with increasing $\mathrm{NO}_{3}^{-}$concentrations. Moreover, they suggested that this effect may be an important DMS loss pathway in nitrate rich surface waters as those typically found in coastal upwelling areas. Furthermore, it was shown that dissolved inorganic carbon (DIC) in seawater is counteracting DMS photochemical degradation by scavenging $\mathrm{Br}_{2}^{-}$radicals (Bouillon and Miller, 2005). The upwelled surface waters off Mauritania in February 2008 were considerably enriched in DIC (Steinhoff, 2010). Thus, the comparably low DMS concentrations at N:P $>7$ (Fig. 6) may, indeed, indicate that a fraction of dissolved DMS was photolysed. However, we speculate that the high DIC concentrations present at the beginning of the upwelling may have reduced DMS photolysis via reaction with $\mathrm{Br}_{2}^{-}$.

\section{Summary}

The upwelling event off Mauritania in February 2008 was dominated by diatoms at the coast, where nutrient rich subsurface water was brought to the surface fuelling the productivity. Further offshore, when the nutrients (especially $\mathrm{NO}_{3}^{-}$) became depleted in the plumes of the upwelling, cyanobacteria were the most abundant phytoplankton species. Maximum concentrations of DMS, $\mathrm{DMSP}_{d}$ and DMSP $_{\mathrm{p}}$ of $10 \mathrm{nmol} \mathrm{L}^{-1}, 15 \mathrm{nmol} \mathrm{L}^{-1}$ and $990 \mathrm{nmol} \mathrm{L}^{-1}$, respectively, were measured. The maximum DMSP $_{p}$ concentration is the highest reported from upwelling regions so far, and indicates that the Mauritanian upwelling is indeed a hot spot of DMSP and, thus, potential DMS production. Analysis of the phytoplankton pigments revealed that dinoflagellates were responsible for the accumulation of DMS, whereas haptophytes (including coccolithophorids) seemed to have played only a minor role for DMS concentration during the time of our study. Nitrogen limitation was identified to be a major factor for DMS and DMSP distribution. A switch from high DMSP concentration to high DMS concentration was observed when the N:P ratio was below 7. We conclude, therefore, that the oxidative stress induced by the increasing $\mathrm{N}$ limitation in combination with the high UV radiation in the tropical Atlantic off Mauritania caused DMSP algae to increase DMSP decomposition, resulting in high DMS concentrations. Photolysis of DMS may have contributed to low DMS concentrations in the freshly upwelled waters. However, SRD together with MLD and chl- $a$ could not explain the DMS surface distributions off Mauritania. Microbial processes such as bacterial consumption of DMS and DMSP can make a significant contribution to the DMS and DMSP distribution. However, these processes have not been investigated in our study. The results from this study are in line with the general observations that coastal upwelling areas are important sites of DMS production. In order to understand the key processes of DMS and DMSP production and to reveal their major driving factors, more studies are needed.

Acknowledgements. We thank the authorities of Mauritania and Cape Verde for the permissions to work in their territorial waters. We acknowledge the support of the captain and crew of R/V L'Atalante as well as the chief scientist of ATA-03, Arne Körtzinger. Moreover, we thank Frank Malien for nutrient measurements during the cruise. We thank the two anonymous reviewers for their helpful comments. Financial support for this study was provided by BMBF grant SOPRAN FKZ 03F0462A.

Edited by: G. Herndl

\section{References}

Andreae, M. O.: Dimethylsulfide in the water column and the sediment porewaters of the Peru upwelling area, Limnol. Oceanogr., 30, 1208-1218, 1985.

Archer, S. D., Smith, G. C., Nightingale, P. D., Widdicombe, C. E., Tarran, G. A., Rees, A. P., and Burkill, P. H.: Dynamics of particulate dimethylsulphoniopropionate during a Lagrangian experiment in the northern North Sea, Deep-Sea Res. II, 49, 29792999, 2002.

Archer, S. D., Ragni, M., Webster, R., Airs, R. L., and Geider, R. J.: Dimethyl sulfoniopropionate and dimethyl sulfide production in response to photoinhibition in Emiliania huxleyi, Limnol Oceanogr, 55, 1579-1589, 2010.

Arrigo, K. R.: Marine microorganisms and global nutrient cycles, Nature, 437, 349-355, 2005.

Barlow, R. G., Mantoura, R. F. C., Gough, M. A., and Fileman, T. W.: Pigment signatures of the phytoplankton composition in the northeastern Atlantic during the 1990 spring bloom, Deep-Sea Res. II, 40, 459-477, 1993.

Barlow, R. G., Cummings, D. G., and Gibb, S. W.: Improved resolution of mono- and divinyl chlorophylls a and $\mathrm{b}$ and zeaxanthin and lutein in phytoplankton extracts using reverse phase C-8 HPLC, Mar. Ecol-Prog. Ser., 161, 119-123, 1997.

Belviso, S. and Caniaux, G.: A new assessment in North Atlantic waters of the relationship between DMS concentration and upper mixed layer solar radiation dose, Global Biogeochem. Cy., 23, GB1014, doi:1010.1029/2008GB003282, 2009.

Belviso, S., Sciandra, A., and Copin-Montégut, C., Mesoscale features of surface water DMSP and DMS concentration in the Atlantic Ocean off Morocco and in the Mediterranean Sea, DeepSea Res. I, 50, 543-555, 2003.

Bidigare, R. R.: Analysis of algal chlorophylls and carotenoids, in: Marine particles: Analysis and Characterisation, edited by: Hurd, D. C. and Spencer D. W., American Geophysical Union, 119-123, 1991. 
Bouillon, R.-C. and Miller, W. L.: Photodegradation of dimethyl sulfide (DMS) in natural waters: Laboratory assessment of the nitrate-photolysis-induced DMS oxidation, Envir. Sci. Tech., 39, 9471-9477, 2005.

Bucciarelli, E. and Sunda, W. G.: Influence of $\mathrm{CO}_{2}$, nitrate, phosphate, and silicate limitation on intracellular dimethylsulfoniopropionate in batch cultures of the coastal diatom Thalassiosira pseudonana, Limnol. Oceanogr., 48, 2256-2265, 2003.

Campbell, L. and Vaulot, D.: Photosynthetic picoplancton community structure in the subtropical North Pacific Ocean near Hawaii (station ALOHA), Deep-Sea Res. II, 40, 2043-2060, 1993.

Charlson, R. J., Lovelock, J. E., Andreae, M. O., and Warren, S. G.: Oceanic phytoplankton, atmospheric sulphur, cloud albedo and climate, Nature, 326, 655-661, 1987.

Chavez, F. P. and Messié, M.: A comparison of Eastern Boundary Upwelling Ecosystems, Prog. Oceanogr., 83, 80-96, 2009.

Chisholm, S. W., Olson, R. J., Zettler, E. R., Goericke, R., Waterbury, J. B., and Welschmeyer, N. A.: A novel free-living prochlorophyte abundant in the oceanic euphotic zone, Nature, 334, 340-343, 1988.

David, H. A.: Further applications of range to analysis of variance, Biometrika, 38, 393-409, 1951.

Derevianko, G. J., Deutsch, C., and Hall, A.: On the relationship between ocean DMS and solar radiation, Geophys Res Lett, 36, L17606, doi:17610.11029/12009GL039412, 2009.

Faloona, I.: Sulfur processing in the marine atmospheric boundary layer: A review and critical assessment of modelling uncertainties, Atmos Environ, 43, 2841-2854, 2009.

Franklin, D. J., Poulton, A. J., Steinke, M., Young, J., Peeken, I., and Malin, G.: Dimethylsulphide, DMSP-lyase activity and microplankton community structure inside and outside of the Mauritanian upwelling, Prog Oceanogr, 83, 134-142, 2009.

Gaul, W.: Untersuchungen zur Produktion und zum mikrobiellen Umsatz von $\beta$-Dimethylsulfoniopropionat, Kiel University, Kiel, (http://eldiss.uni-kiel.de/macau/receive/dissertation diss_00001320), 88 pp., 2004.

Goericke, R. and Welschmeyer, N. A.: The marine prochlorophyte Prochlorococcus contributes significantly to phytoplankton biomass and primary production in the Sargasso Sea, Deep-Sea Res. I, 40, 2283-2294, 1993.

Hansen, H. P. and Koroleff, F.: Determination of nutrients, in: Methods of seawater analysis, edited by: Grasshoff, K., Kremling, K., and Ehrhardt, M., Wiley-VCH, Weinheim, 159-228, 1999.

Harada, H., Vila-Costa, M., Cebrian, J., and Kiene, R. P.: Effects of $\mathrm{UV}$ radiation and nitrate limitation on the production of biogenic sulfur compounds by marine phytoplankton, Aquat. Bot., 90, 3742, 2009.

Hatton, A. D., Malin, G., and Liss, P. S.: Distribution of biogenic sulphur compounds during and just after the southwest monsoon in the Arabian Sea, Deep-Sea Res. II, 46, 617-632, 1999.

Jeffrey, S. W., Mantoura, R. F. C., and Bjørnland, T.: Data for the identification of 47 key phytoplankton pigments, in: Phytoplankton pigments in oceanography: Guideline to modern methods, edited by: Jeffrey, S. W., Mantoura, R. F. C., and Wright, S. W., UNESCO Publishing, 449-559, 1997.

Kara, B. A., Rochford, P. A., and Hurlburt, H. E.: An optimal definition for ocean mixed layer depth, J. Geophys. Res., 105, 1680316821,2000
Keller, M. D., Bellows, W. K., and Guillard, R. R. L.: Dimethyl sulfide production in marine phytoplankton, in: Biogenic sulfur in the environment, edited by: Saltzman, E. D., and Copper, W. J., ACS Symposium Series No. 393, American Chemical Society, Washington DC, 167-182, 1989.

Kettle, A. J. and Andreae, M. O.: Flux of dimethylsulfide from the oceans: A comparison of updated data sets and flux models, J. Geophys. Res., 105, 26793-26808, 2000.

Kiene, R. P.: Measurement of dimethylsulfid (DMS) and dimethylsulfoniopropionate (DMSP) in seawater and estimation of DMS turnover rates, in: Handbook of Methods in Aquatic microbial Ecology, Lewis Publishers, 601-610, 1993.

Kiene, R. P. and Slezak, D.: Low dissolved DMSP concentrations in seawater revealed by small-volume gravity filtration and dialysis sampling, Limnol. Oceanogr. Meth., 4, 80-95, 2006.

Lana, A., Bell, T. G., Simó, R., Vallina, S. M., BallabreraPoy, J., Kettle, A. J., Dachs, J., Bopp, L., Saltzman, E. S., Johnson, J. E., and Liss, P. S.: An updated climatology of surface dimethylsulfide concentrations and emission fluxes in the global ocean, Global Biogeochem. Cy., 25, GB 1004, doi:10.1029/2010GB003850, 2011.

Leck, C., Larsson, U., Bagander, L. E., Johansson, S., Hajdu, S.: Dimethyl sulfide in the Baltic Sea - annual variability in relation to biological-activity, J. Geophys. Res., 95, 3353-3363, 1990.

Louda, J. W. and Baker, E. W.: The biochemistry of pigments, in: Organic marine geochemistry, edited by: Sohn, M. L., ACS Symposium Series, American Chemical Society, 107-126, 1986.

Mackey, M. D., Mackey, D. J., Higgings, H. W., and Wright, S. W.: CHEMTAX - a program for estimating class abundances from chemical markers: application to HPLC measurements of phytoplankton, Mar. Ecol-Prog. Ser., 144, 265-283, 1996.

Minas, J. H., Minas, M., and Packard, T. T.: Productivity in upwelling areas deduced from hydrographic and chemical fields, Limnol. Oceanogr., 31, 1182-1206, 1986.

Mittelstaedt, E.: The ocean boundary along the northwest African coast: Circulation and oceanographic properties at the sea surface, Prog. Oceanogr., 26, 307-355, 1991.

Nguyen, B. C., Belviso, S., and Mihalopoulos, N.: Dimethyl sulfide production during natural phytoplanktonic blooms, Mar. Chem., 24, 133-141, 1988.

Riseman, S. F. and DiTullio, G. R.: Particulate dimethylsulfoniopropionate and dimethylsulfoxide in relation to iron availability and algal community structure in the Peru Upwelling System, Can. J. Fish. Aquat. Sci, 61, 721-735, 2004.

Saló, V., Simó, R., and Calbert, A.: Revisiting the dilution technique to quantify the role of microzooplankton in DMS(P) cycling: laboratory and field tests, J Plankton Res., 32, 1255-1267, 2010.

Schäfer, H., Myronova, N., and Boden, R.: Microbial degradation of dimethylsulfide and related C1-sulphur compounds: Organisms and pathways controlling fluxes of sulphur in the biosphere, J. Exp. Bot., 61, 315-334, 2010.

Shenoy, D. M. and Dileep Kumar, M.: Variability in abundance and fluxes of dimethyl sulphide in the Indian Ocean, Biogeochemistry, 83, 277-292, 2007.

Shuman, F. R. and Lorenze, C. J.: Quantitative degradation of chorophyll by a marine herbivore, Limnol. Oceanogr., 20, 580586, 1975.

Simó, R.: Trace chromatophraphic analysis of dimethyl sulfoxide 
and related methylated sulfur compounds in natural waters, J. Chromatogr. A, 807, 151-164, 1998.

Simó R.: From cells to globe: approaching the dynamics of DMS(P) in the ocean at multiple scales, Can. J. Fish. Aquat. Sci, 61, 673-684, 2004.

Simó, R. and Dachs, J.: Global ocean emission of dimethylsulfide predicted from biogeophysical data, Global Biogeochem. Cy., 16, 1078, doi:10.1029/2001GB001829, 2002.

Simó, R., Archer S. D., Pedrós-Alió C., Gilpin L., and StelfoxWiddicombe C. E.: Coupled dynamics of dimethylsulfoniopropionate and dimethylsulfide cycling and the microbial food web in surface waters of the North Atlantic, Limnol. Oceanogr., 47, 53-61, 2002

Stefels, J., Steinke, M., Turner, S., Malin, G., and Belviso, S.: Environmental constraints on the production and removal of the climatically active gas dimethylsulphide (DMS) and implications for ecosystem modeling, Biogeochemistry, 83, 245-275, 2007.

Steinhoff, T.: Carbon and nutrient fluxes in the North Atlantic Ocean, Kiel Universität, Kiel, 162 pp., 2010.

Steinke, M., Malin, G., Archer, S., Burkill, P. H., and Liss, P. S.: DMS production in a coccolithophorid bloom: Evidences for the importance of dinoflagellate DMSP lyases, Aquat. Microb. Ecol., 26, 259-270, 2002.

Sunda, W., Kieber, D. J., Keine, R. P., and Huntsman, S.: An antioxidant function for DMSP and DMS in marine algae, Nature, 418, 317-320, 2002.
Sunda, W. G., Hardison, R., Kiene, R. P., Bucciarelli, E., and Harada, H.: The effect of nitrogen limitation on cellular DMSP and DMS release in marine phytoplankton: climate feedback implications, Aquat. Sci., 69, 341-351, 2007.

Toole, D. A., Kieber, D. J., Keine, R. P., White, E. M., Bisgrove, J., del Valle, D. A., and Slezak, D.: High dimethylsulfide photolysis rates in nitrate-rich Antarctic waters, Geophy. Res. Lett., 31, L11307, doi:10.1029/2004GL019863, 2004.

Vallina, S. M. and Simó, R.: Strong relationship between DMS and the solar radiation dose over the global surface ocean, Science, 315, 506-508, 2007.

Veldhuis, M. J. W. and Kraay, G. W.: Phytoplankton in the subtropical Atlantic Ocean; towards a better understanding of biomass and composition, Deep-Sea Res. I, 54, 507-530, 2004.

Vogt, M. and Liss, P. S.: Dimethylsulfide and climate, in: Surface Ocean - Lower Atmosphere Processes, edited by: Le Quéré, C., and Saltzman, E. S., American Geophysical Union, Washington, DC, 197-232, 2009.

Waterbury, J. W., Watson, S. W., Valois, F. W., and Franks, D. G.: Biological and ecological characterization of the marine unicellular Cyanobacterium Synechococcus, Can. B. Fish. Aquat. Sci., 214, 71-120, 1986.

Wolfe, G. V.: Grazing-activated production of dimethyl sulfide (DMS) by two clones of Emiliania huxelyi, Limnol. Oceanogr., 41, 1151-1160, 1996. 